\title{
EXPERIMENTAL DESIGN APPROACH FOR THE DEVELOPMENT AND VALIDATION OF AN ENANTIOSPECIFIC RP-HPLC METHOD FOR SIMULTANEOUS DETERMINATION OF CLOPIDOGREL AND RELATED COMPOUNDS
}

\author{
Rumenka Petkovska ${ }^{1}$, Claus Cornett ${ }^{2}$, Aneta Dimitrovska ${ }^{1}$ \\ ${ }^{1}$ Department of Chemistry, Faculty of Pharmacy, "SS Cyril and Methodiys” University, \\ Vodnjanska 17, 1000 Skopje, Republic of Macedonia \\ ${ }^{b}$ Department of Pharmaceutics and Analytical Chemistry, Faculty of Pharmacy, Copenhagen University, \\ Universitetsparken 2, 2100 Copenhagen, Denmark \\ rupe@ff.ukim.edu.mk
}

\begin{abstract}
An enantiospecific RP-HPLC method was developed and validated for the simultaneous determination of clopidogrel and four related compounds specified as impurities. Experimental design was applied during the method optimization (Full factorial $2^{3}$ design) and robustness testing (Central Composite Face Centered design). Laboratory mixtures of clopidogrel and its impurities in a concentration ratio of 1: $5.0 \times 10^{-4}$ were used as an investigation matrix. The three independent variables were the acetonitrile content in the mobile phase, $\mathrm{pH}$ of the mobile phase, and the column temperature. A Chromatographic Response Function (CRF) was used for estimation of the system response resolution $\left(\mathrm{R}_{\mathrm{s}}\right)$. Separation was achieved using mobile phase composition of ACN: Buffer solution $\mathrm{pH} 6.5(40: 60 \mathrm{v} / \mathrm{v})$ at $30^{\circ} \mathrm{C}$. A CHIRAL-AGP $4.0 \mathrm{~mm} \times 100 \mathrm{~mm}, 5.0 \mu \mathrm{m}$ particle size column was used. The total time for chromatographic separation was approximately $10.0 \mathrm{~min}$. The method was validated for its selectivity, linearity, precision, accuracy and robustness.
\end{abstract}

Key words: experimental design; enantiomer separation; clopidogrel; impurities; method development; validation

\section{РАЗВОЈ И ВАЛИДАЦИЈА НА ЕНАНТИОСПЕЦИФИЧЕН RP-HРLC-МЕТОД ЗА ЕДНОВРЕМЕНО ОПРЕДЕЛУВАЊЕ НА КЛОПИДОГРЕЛ И НЕГОВИТЕ СРОДНИ СУПСТАНЦИИ СО ПРИМЕНА НА ЕКСПЕРИМЕНТАЛНО ДИЗАЈНИРАЫЕ}

Енатиоспецифичен RP-HPLC-метод беше развиен и применет за едновремено определување на клопидогрел и негови сродни супстанции. Експерименталното дизајнирање беше применето во текот на оптимизација (целосен факторски $2^{3}$ дизајн) и утврдување на робусност (Central Compisite Face Centered design) на методот. Медиум за испитување беше раствор на клопидогрел и четири сродни супстанции во концентрациски однос $1: 5,0 \times 10^{-4}$, соодветно. Беше утврдено влијанието на уделот на ацетонитрил во мобилната фаза, $\mathrm{pH}$ на мобилната фаза и температурата на колоната. Процената на значајноста на влијанието од испитуваните фактори беше вршена преку резолуцијата $\left(R_{s}\right)$ меѓу добиените пикови и функцијата на хроматографски одговор (CRF). Оптимално раздвојување беше постигнато со примена на CHIRAL-AGP $4.0 \mathrm{~mm} \times 100 \mathrm{~mm}, 5,0 \mu \mathrm{m}$ колона, ацетонитрил : пуфер рН 6.5 (40:60 v/v) како мобилна фаза, на $30^{\circ} \mathrm{C}$ за време од околу 10 минути. Методот беше валидиран преку определување на селективност, линеарност, точност, прецизност и робусност.

Клучни зборови: експериментално дизајнирање; хирална сепарација; клопидогрел; онечистувања; развој на метод; валидација

\section{INTRODUCTION}

Clopidogrel is a selective adenosine diphosphate (ADP) receptor antagonist that is indicated in the reduction of atherosclerotic events including myocardial infarction, ischemic stroke and vascular death in patients with atherosclerosis manifested by recent stroke, myocardial infarction or estab- 
lished peripheral vascular disease. Clopidogrel is an inactive prodrug and a biotransformation by the liver is necessary to induce expression of its antiaggregating activity $[1,2]$.

Chemically, clopidogrel hydrogen sulphate is methyl (+)-(S)-(2-chlorophenyl)-(6,7-dihydro-4Hthieno [3,2-c] pyridin-5-yl)-acetate hydrogen sulphate. It is a thienopyridine derivative chemically related to ticlodipine. The molecule is a thienopyridine derivative containing an asymmetric carbon leading to the existence of two enantiomers ( $R$ and $S$ ). Studies showed that the active compound clopidogrel is the $S$-enantiomer [3]. This implies that the content of the $R$-enantiomer must be carefully controlled in clopidogrel therapeutically active substance. For clopidogrel, four related compounds are specified as impurities: (R)-(2-chlorophenyl)(6,7-dihydro-4H-thieno[3,2-c] pyridin-5-yl)-acetic acid methyl ester ( $R$-enantiomer), $(R, S)$-(2-chlorophenyl)-(5,7-dihydro-4H-thieno[2,3-c] pyridin6-yl)-acetic acid methyl ester (Imp. 1) and (S)-(2chlorophenyl)-(6,7-dihydro-4H-thieno[3,2-c]py-ridin-6-yl)-acetic acid (Imp. 2). Impurity 1 is a process-related impurity and it may be present in the drug substance as racemic mixture (Imp. 1a and Imp.1b). Impurity 2 is the main degradation impurity obtained by hydrolysis of the ester group due the action of combined moisture and temperature. The chemical structure of clopidogrel hydrogen sulphate (CLP) and non salified related substances is shown in Fig. 1.

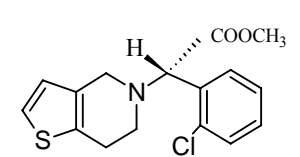

Clopidogrel (S-enantiomer)

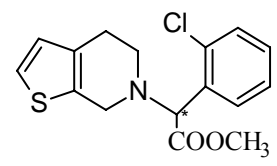

Impurity 1
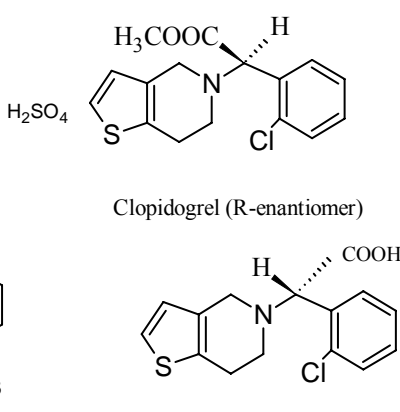

Impurity 2
Clopidogrel (R-enantiomer)

Fig. 1. Chemical structure of clopidogrel hydrogen sulphate and its related compounds

A literature search has revealed few reported methods for determination of clopidogrel hydrogen sulphate. A non-stereo specific liquid chromatographic (LC) method for the determination of clopidogrel in oral dosage form has been validated and used for degradation studies under stress conditions [4]. An enantiospecific LC method for separation of clopidogrel and its R-enantiomer was developed and used for analysis of purity in 19 drug products [5]. For the analysis of the carboxylic acid metabolite of clopidogrel in plasma and serum, LC-MS methods [6, 7] and HPLC method [8] have been described. To the best of our knowledge, a chemometrics approach for development and validation of an enantiospecific HPLC method for simultaneous determination of clopidogrel and all above mentioned related compounds has not been reported thus far.

This manuscript describes the development and validation of a rapid, simple, robust enantiospecific HPLC method for simultaneous determination of CLP and its related substances using Design of Experiments (DoE) approach. Development and validation of the method were performed using experimental design for method optimization and robustness resting. The chemometric approach requires a relatively limited number of experiments to define the factors which affect the chromatographic behavior of investigated substances and to obtain optimum conditions for their analysis.

\section{EXPERIMENTAL}

Chemicals and reagents. All reagents used were of at least analytical grade. Acetonitrile, ACN (gradient grade, Merck, Darmstadt, Germany), water (HPLC grade), di-potassium hydrogen phosphate, $\mathrm{K}_{2} \mathrm{HPO}_{4}$, (analytical grade, Merck, Darmstadt, Germany) and $85 \%$ orthophosphoric acid were used to prepare the mobile phase. Methanol (analytical grade, Merck, Darmstadt, Germany) and phosphate buffer solution with $\mathrm{pH} 4.0$ were used as solvents. Phosphate buffer solution $(0.015$ $\mathrm{M})$ was prepared by dissolving $2.72 \mathrm{~g}$ di-potassium hydrogen phosphate in $900 \mathrm{ml}$ of water. $\mathrm{pH}$ was adjusted with $85 \%$ orthophosphoric acid solution and the volume was made up to $1000 \mathrm{ml}$ with water. Clopidogrel hydrogen sulphate (CLP), Renantiomer, Impurity 1 (as racemic mixture) and Impurity 2 were kindly supplied by Sanofi-Synterlabo, Sanofi Chemie, Sisterion, France.

Standard solutions. Standard stock solutions were prepared by dissolving the respective working standard substances in methanol to obtain the concentration of $500.0 \mu \mathrm{g} \mathrm{ml}^{-1}$ for CLP and $5.0 \mu \mathrm{g} \mathrm{ml}^{-1}$ for all related compounds (R-enantiomer, Imp. 1 and Imp. 2). 
Validation procedure. In order to study linearity of the response, a series of working standard solutions (10.0, 20.0, 30.0, 40.0, 50.0, 60.0, 70.0, 80.0, 90.0 and $100.0 \mu \mathrm{g} \mathrm{ml}^{-1}$ for CLP and of 5.0, $10.0,15.0,20.0,25.0,30.0,35.0,40.0,45.0$ and $50.0 \mathrm{ng} \mathrm{ml}^{-1}$ for each related compound) were prepared. Three determinations were carried out for each solution. The linearity of the peak area responses versus concentration was studied. The correlation graph was constructed by plotting the peak areas obtained at the optimized conditions. Precision and accuracy were assessed using three different working standard solutions in the range of $50-150 \%$ of the test concentration $\left(20.0 \mu \mathrm{g} \mathrm{ml}^{-1}\right.$, $50.0 \mu \mathrm{g} \mathrm{ml}^{-1}$ and $80.0 \mu \mathrm{g} \mathrm{ml} \mathrm{m}^{-1}$ of CLP; $10.0 \mathrm{ng} \mathrm{ml}^{-1}, 25.0 \mathrm{ng} \mathrm{ml}^{-1}$ and $40.0 \mathrm{ng} \mathrm{ml}^{-1}$ of each related compound). Intra-day accuracy and precision were evaluated from replicate analysis $(n=6)$ of working standard solutions on the same day. Inter-day accuracy and precision were also assessed from the analysis of the same working standard solutions in replicate, during two separate, successive days $(n=12)$. For wavelength selection, standard solutions of $50.0 \mu \mathrm{g} \mathrm{ml}^{-1}$ for CLP and $25.0 \mathrm{ng} \mathrm{ml}^{-1}$ of each related compound were prepared. The standard stock solution was diluted to obtain working standard solutions. Phosphate buffer solution $\mathrm{pH}$ 4.0: methanol $(90: 10 \mathrm{v} / \mathrm{v})$ was used as solvent for all preparations.

Test solutions. A test solution was prepared containing a mixture of clopidogrel hydrogen sulphate and related compounds in a concentration ratio corresponding to the recommendations by the ICH (International Conference on Harmonization of Technical Requirements for Registration of Pharmaceuticals for Human Use), Topic Q3A(R2), [9]. The test solution containing $50.0 \mu \mathrm{g} \mathrm{ml}^{-1}$ CLP and $25.0 \mathrm{ng} \mathrm{ml}^{-1}$ of each related compound (corresponding to $0.05 \%$ of the concentration of CLP) was prepared using standard stock solutions. In all experiments, the test solution was used to acquire the chromatograms. Injection of individual working standard solutions (containing only one compound) was used for peak identification. Only chromatograms acquired with the test solution were used in the calculation of the chromatographic responses.

Apparatus. Agilent Rapid Resolution HPLC system, 1200 series (consisted of a Binary pump SL, a Diode Array Detector SL, Column compartment TCC SL) was used. The samples were introduced through a High Performance Auto sampler
SL (HIP-ALS SL). A single UV absorbance was measured at $220 \mathrm{~nm}$. The peak areas were integrated automatically with Windows NT based LC ChemStation Software. The MODDE 8.0 Software for design of experiments and optimization (Umetrics, Umea, Sweden) was used for generation and evaluation of the experimental designs.

Chromatographic conditions. Separations were performed using a CHIRAL-AGP $4.0 \mathrm{~mm} \times$ $100 \mathrm{~mm}, 5.0 \mu \mathrm{m}$ particle size column. The wavelength was selected by scanning working standard solutions of all investigated compounds over 200 to $400 \mathrm{~nm}$ wavelengths. All measurements were made with $10 \mu \mathrm{l}$ injection volume and UV detection at $220 \mathrm{~nm}$ because all components showed reasonable good response at this wavelength. Mobile phases were prepared using acetonitrile and 0.015 $\mathrm{M}$ phosphate buffer solution. All mobile phases were filtered through a $0.2 \mu \mathrm{m}$ Millipore filter.

Optimization. For the optimization procedure, a Full factorial $2^{3}$ design was applied. Acetonitrile $(\mathrm{ACN})$ content in the mobile phase, $\mathrm{pH}$ value of the mobile phase, and the column temperature were investigated in three different levels of each. ACN content was varied from $25 \pm 0.5 \%$ to $55 \pm$ $0.5 \%(\mathrm{v} / \mathrm{v})$. The $\mathrm{pH}$ values of the buffer solution were varied between $3.0 \pm 0.1$ and $6.5 \pm 0.1$. pH values were adjusted with $85 \%$ ortophosphoric acid before mixing with $\mathrm{ACN}$. The temperature of the column was varied from $20 \pm 0.1{ }^{\circ} \mathrm{C}$ to $40 \pm$ $0.1{ }^{\circ} \mathrm{C}$.

Robustness. Robustness testing was performed in accordance with a Central Composite Face Centered (CCF) Design. Three basic composition of the mobile phase were tested where the ACN content in the mobile phase was varied from $25 \pm 0.5 \%$ to $35 \pm 0.5 \%(\mathrm{v} / \mathrm{v})$ and the $\mathrm{pH}$ values of the buffer solution were varied from $6.0 \pm 0.1$ to $7.0 \pm 0.1$. The column temperature was varied between $25 \pm 0.1^{\circ} \mathrm{C}$ and $35 \pm 0.1^{\circ} \mathrm{C}$. For estimation of the system response during optimization procedure and robustness testing, resolution $\left(R_{s}\right)$ and a Chromatographic Response Function (CRF) were used as response factors.

\section{RESULTS AND DISCUSSION}

Chromatographic behavior of CLP and its related substances was examined using CHIRALAGP column. The chiral selector in the stationary phase is alpha1-acid glycoprotein (AGP). This 
very stable protein has been immobilized onto spherical $5 \mu \mathrm{m}$ silica particles. The protein tolerates high concentrations of organic solvents, high and low $\mathrm{pH}(2.0-7.0)$, and high temperature. The column can be used for direct resolution of enantiomers without derivatization [10]. During the preliminary investigation, several mobile phases were examined containing ACN - buffer solution at various ratios, with $\mathrm{pH}$ values of the buffer solution between 3.0 and 6.5. The column temperature was varied between $20{ }^{\circ} \mathrm{C}$ and $40{ }^{\circ} \mathrm{C}$. It was observed that $\mathrm{pH}$ variations between 3.0 and $6.5 \mathrm{did}$ not significantly affect retention or resolution, as expected considering the $p K a$ value of CLP $(p K a=4.5)$ and structure similarity of the related compounds. In general, on the chiral stationary phase, enantiomers are better separated when they are not in ionic form. Therefore, acidic compounds are usually better resolved in acidic conditions. On the other hand, CLP is a weak base, thereby at $\mathrm{pH}$ values below 3.0 its retention is decreased due to protonation. From the preliminary investigations it was confirmed that enantioselectivity was observed, but the obtained separation was insufficient. Acetonitrile content (v/v \%) in the mobile phase, $\mathrm{pH}$ value of mobile phase and column temperature were the important factors affecting separation. Increasing the ACN content in the mobile phase and column temperature had significant influence on retention and separation. Temperature variations can change the viscosity of the mobile phase and ionization extent of the investigated compounds, and influence the retention mechanism.

The hold-up time $\left(t_{0}\right)$ for the column used was estimated by replicate injection of methanol under three different column temperature values $\left(20^{\circ} \mathrm{C}\right.$, $30{ }^{\circ} \mathrm{C}$ and $40{ }^{\circ} \mathrm{C}$ ). It was found that $\mathrm{t}_{\mathrm{o}}$ variations were not more than $5 \mathrm{~s}$ over the range of temperature from 20 to $40{ }^{\circ} \mathrm{C}$. These changes in $t_{0}$ were in the same direction as the corresponding changes obtained for the retention of the investigated compounds. Hence, for calculation of the capacity factors of the compounds eluted from given column, uniform values of $t_{0}(0.9 \mathrm{~min})$ was used.

The optimum chromatographic conditions for enantioselective separation are usually selected by trial and error, which is tedious and troublesome. As the objective of the method was to resolve CLP and related impurities in short analysis time with no compromise in resolution, selectivity and robustness, a Full factorial $2^{3}$ design for simultane- ous three factor optimization of the separation of a mixture of CLP and its impurities was used. The method is based on modeling the resolution $\left(R_{s}\right)$ using a polynomial of three-factors according to a rectangular design. The three factors varied were: $\left(x_{1}\right)$ acetonitrile content $(\mathrm{v} / \mathrm{v} \%)$ in the mobile phase, $\left(x_{2}\right) \mathrm{pH}$ value of mobile phase, and $\left(\mathrm{x}_{3}\right)$ column temperature, and they were investigated in three different levels of each. A zero-level (center) in which all variables are fixed at their mean value, is included in order to minimize the risk of missing non-linear relationships. This experiment is not included in the calculation of coefficients [11]. For estimation of the system response, the resolution $\left(R_{s}\right)$ between peak pairs was chosen. A minimum obtained value of individual $R_{\mathrm{s}}$-values of 1.5 as a selection criterion was used [12]. Selecting $R_{s}$ for measuring the response was done in order to avoid inaccurate conclusions, e.g. selecting wrong separation parameters in case of overlapping peaks. Fifteen experiments (including three zero-level experiments) were carried out and the $R_{S}$ values for all consecutive peak pairs were calculated. The total number of detected peak pairs was four: (I) Imp.2/Imp.1a; (II) Imp.1a/CLP; (III) CLP/Imp.1b; (IV) Imp.1b/R-enantiomer. The elution order did not change with the mobile phases tested. These results are presented in Table 1.

In Full factorial $2^{3}$ experimental design a linear mathematical model of the measured response is often applied for the evaluation of the influence of the investigated factors. An often used linear model is:

$\begin{aligned} y= & b_{\mathrm{o}, \mathrm{o}}+b_{1} x_{1}+b_{2} x_{2}+b_{3} x_{3}+b_{1,2} x_{1} x_{2}+ \\ & +b_{1,3} x_{1} x_{3}+b_{2,3} x_{2} x_{3}+b_{1,2,3} x_{1} x_{2} x_{3}\end{aligned}$

Where $y$ represents the estimated response, $b_{\mathrm{o}}$ is the average experimental response, coefficients $b_{1}, b_{2}$, and $b_{3}$ are the estimated effects of the factors considered. The extent to which these terms affect the performance of the method is called the main effect. The coefficients $b_{1,2}, b_{1,3}, b_{2,3}$ and $b_{1,2,3}$ are called interaction terms. In this way, the factorial design provides information about the importance of interaction between the factors. The zero-level experiment was not included in the calculation of the coefficients. Also, $b_{0}$ is the intercept of the linear model, $b_{1}, b_{2}$ and $b_{3}$ are the main effects, $b_{1,2}$, $b_{1,3}$ and $b_{2,3}$ are two-factor interactions, and $b_{1,2,3}$ are a three-factor interaction [13]. The values of the obtained coefficients are listed in Table 2. 
Table 1

The $R_{s}$ values of the eluted peak pairs

\begin{tabular}{ccccccccc}
\hline \hline & & & & \multicolumn{5}{c}{ Eluted peak pairs* } \\
Exp. No & $x_{1}(\%)$ & $x_{2}$ & $x_{3}\left({ }^{\circ} \mathrm{C}\right)$ & & & & \\
\hline 1 & 25 & 3.0 & 20 & 4.32 & 1.12 & 1.11 & 8.48 & 13.76 \\
2 & 55 & 3.0 & 20 & 3.13 & 1.03 & 1.08 & 8.57 & 29.69 \\
3 & 25 & 6.5 & 20 & 5.48 & 1.30 & 1.42 & 8.56 & 34.45 \\
4 & 55 & 6.5 & 20 & 4.69 & 0.94 & 1.06 & 7.93 & 17.81 \\
5 & 25 & 3.0 & 40 & 5.31 & 1.23 & 1.39 & 7.68 & 22.89 \\
6 & 55 & 3.0 & 40 & 3.98 & 1.09 & 1.15 & 8.30 & 25.56 \\
7 & 25 & 6.5 & 40 & 5.79 & 1.35 & 1.47 & 8.51 & 34.67 \\
8 & 55 & 6.5 & 40 & 4.53 & 1.27 & 1.36 & 7.89 & 35.67 \\
9 & 25 & 5.5 & 20 & 5.27 & 1.34 & 1.29 & 8.53 & 31.42 \\
10 & 55 & 5.5 & 20 & 4.32 & 1.28 & 1.16 & 7.79 & 29.42 \\
11 & 25 & 5.5 & 40 & 4.41 & 1.13 & 1.13 & 7.95 & 27.97 \\
12 & 55 & 5.5 & 40 & 3.87 & 1.07 & 0.99 & 6.98 & 21.03 \\
13 & 40 & 5.5 & 30 & 4.98 & 1.46 & 1.51 & 8.38 & 31.49 \\
14 & 40 & 5.5 & 30 & 5.02 & 1.45 & 1.50 & 8.40 & 31.55 \\
15 & 40 & 5.5 & 30 & 5.01 & 1.46 & 1.51 & 8.39 & 31.55 \\
\hline \hline
\end{tabular}

$\left(x_{1}\right)$ acetonitril content $(\mathrm{v} / \mathrm{v}, \%)$ in the mobile phase; $\left(x_{2}\right) \mathrm{pH}$ of the mobile phase and $\left(x_{3}\right)$ column temperature *Eluted peak pairs refer the text.

Table 2

Values of the obtained coefficients (Eq.1).

\begin{tabular}{lcccccccc}
\hline \hline & \multicolumn{7}{c}{ The values of the obtained coefficients } & \\
& $b_{0}$ & $b_{1}$ & $b_{2}$ & $b_{3}$ & $b_{12}$ & $b_{13}$ & $b_{23}$ & $b_{123}$ \\
\hline The peak pairs & & & & & & & & \\
Imp.2/Imp.1a & 1.66 & 0.54 & 0.07 & -0.12 & 0.12 & -0.08 & -0.03 & 0.09 \\
Imp.1a/CLP & 2.76 & $\mathbf{- 1 . 9 6}$ & 0.19 & $\mathbf{- 1 . 1 8}$ & -0.04 & $\mathbf{0 . 6 4}$ & -0.01 & 0.05 \\
CLP/Imp.1b & 3.22 & $\mathbf{- 1 . 4 1}$ & 0.13 & $\mathbf{- 1 . 0 5}$ & -0.05 & $\mathbf{0 . 4 5}$ & -0.08 & 0.07 \\
Imp.1b/R-enantiomer & 1.21 & -0.37 & 0.06 & -0.20 & -0.02 & 0.03 & -0.01 & 0.01 \\
\hline \hline
\end{tabular}

The values of coefficients $b_{3}$ for the second (Imp.1a/CLP) and the third (CLP/Imp.1b) peak pair, and especially values of coefficients $b_{1}$ for all peak pairs, demonstrate that separation of the investigated substances as measured by the $R_{s}$ values is most affected by the $\left(x_{1}\right)$ acetonitril content $(\mathrm{v} / \mathrm{v} \%)$ in the mobile phase and $\left(x_{3}\right)$ column temperature. The value of the coefficients for the two-factor interaction, $b_{1,3}$ for the second (Imp.1a/CLP) and the third (CLP/Imp.1b) peak pair, confirmed the main factor effects. The $\mathrm{pH}$ value of the mobile phase had the lowest influence on the investigated system responses. In order to investigate the chromatographic behavior of the investigated substances for the given experimental range, and to define the optimum separation conditions, further 
optimization of the method was performed using Response Surface Methodology (RSM). This is a collection of mathematical and statistical techniques useful for analyzing problems where several independent variables influence a dependent variable or a response, and the goal is to optimize this response [14]. A response surface can be defined as a graph in one dimension (one factor of interest) or a surface in two dimensions (two factors of interest) when a response variable is plotted as a function of one or more (quantitative) factors. A Chromatographic Response Function (CRF) was used for optimizing the separation quality of CLP and its impurities in such a way that a maximum resolution with the minimum assay time was obtained. The CRF is a coefficient which characterizes the quality of the separation in quantitative manner, preferably, a flexible function that allows resolution criteria to be specified [15]. The corresponding terms in the chromatogram are then compared to these criteria. In this work a very simple but useful CRF was used:

$$
C R F=\prod_{i=1}^{L-1} R_{S}(i, i+1)
$$

where $R_{s}(i, i+1)$ is the resolution between peak No. $i$ and peak No. $i+1$.

A minimum obtained value of individual $R_{\mathrm{s}^{-}}$ values of 1.5 as a selection criterion was used. The total number of detected peaks pairs (L) was four. CRF values were calculated for all fifteen experiments (Table 1), and contour diagrams were constructed (Fig. 2). Contour diagrams presents the $\mathrm{CRF}$ values as a function of $\left(x_{1}\right)$ acetonitril content $(\mathrm{v} / \mathrm{v}, \%)$ in the mobile phase and $\left(x_{3}\right)$ column temperature on the separation of the investigated substances while $\left(x_{2}\right) \mathrm{pH}$ value of mobile phase was kept constant at 3.0 (Fig. 2a), at 5.5 (Fig. 2b) and at 6.5 (Fig. 2c).

There was no significant influence of $\mathrm{pH}$ value of the mobile phase in the range $3.0-6.5$ on the considered response. Acetonitrile content $(\mathrm{v} / \mathrm{v}$, $\%)$ in the mobile phase and column temperature had the largest influence on resolution. At $\mathrm{pH} 3.0$ sufficient resolution was obtained at 36-42\% $\operatorname{ACN}(\mathrm{v} / \mathrm{v}$,$) and column temperature 26-33{ }^{\circ} \mathrm{C}$ (CRF from 20.7 to 26.3) (Fig. 2a), while at $\mathrm{pH} 5.5$ sufficient resolution was obtained at $39-46 \%$ ACN (v/v,) and column temperature $28-33{ }^{\circ} \mathrm{C}$ (CRF from 30.5 to 35.1) (Fig. 2b).

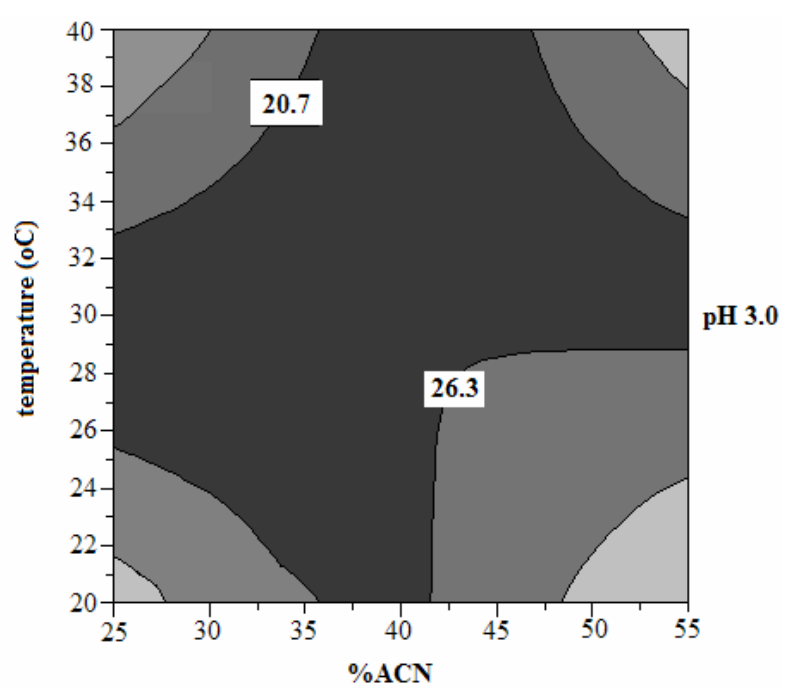

(a)

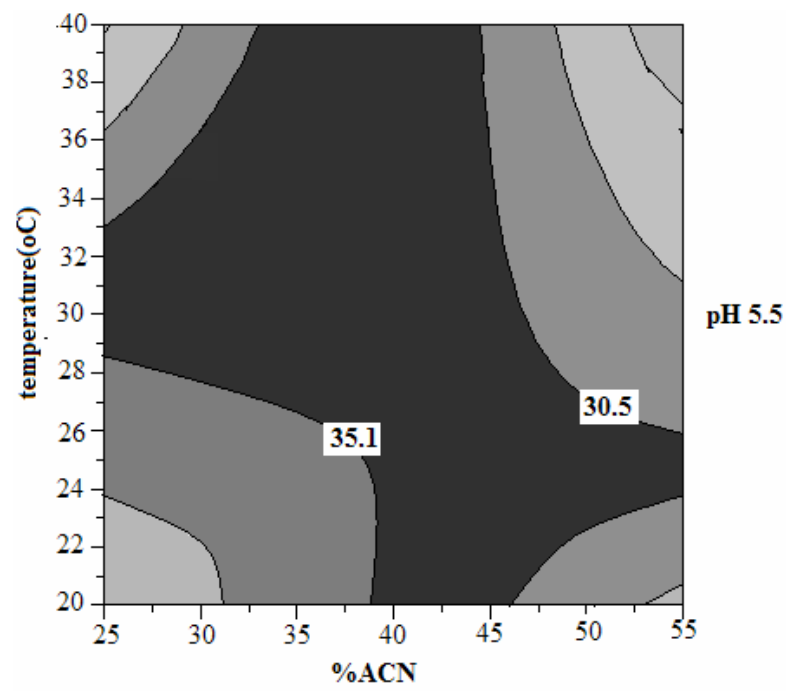

(b)

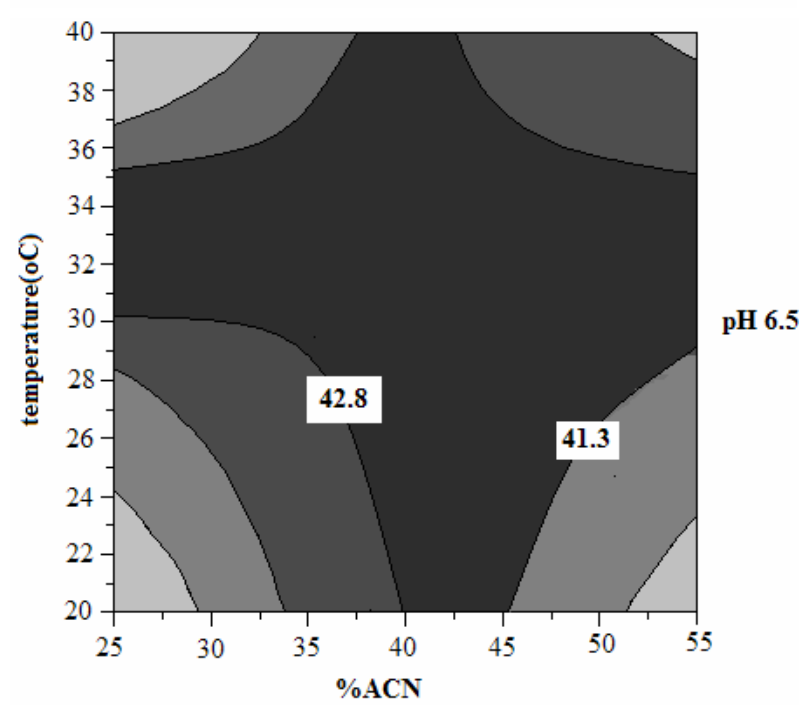

(c)

Fig. 2. A contour diagram of the $\mathrm{CRF}$ as a function of $\mathrm{ACN}$ content in the mobile phase, $\mathrm{pH}$ value of the mobile phase and column temperature 
The best result, which corresponds to high values of the CRF (41.3-42.8), was obtained using buffer solution $\mathrm{pH} 6.5, \mathrm{ACN}$ content from 40 to 45 $\%$ and column temperature from 30 to $35{ }^{\circ} \mathrm{C}$. The mobile phase composition of ACN:Buffer solution
$\mathrm{pH} 6.5(40: 60, \mathrm{v} / \mathrm{v})$ at a temperature of $30{ }^{\circ} \mathrm{C}$ was chosen as optimum conditions for separation. The representative chromatogram of the test solution obtained under optimized conditions is presented in Fig. 3.

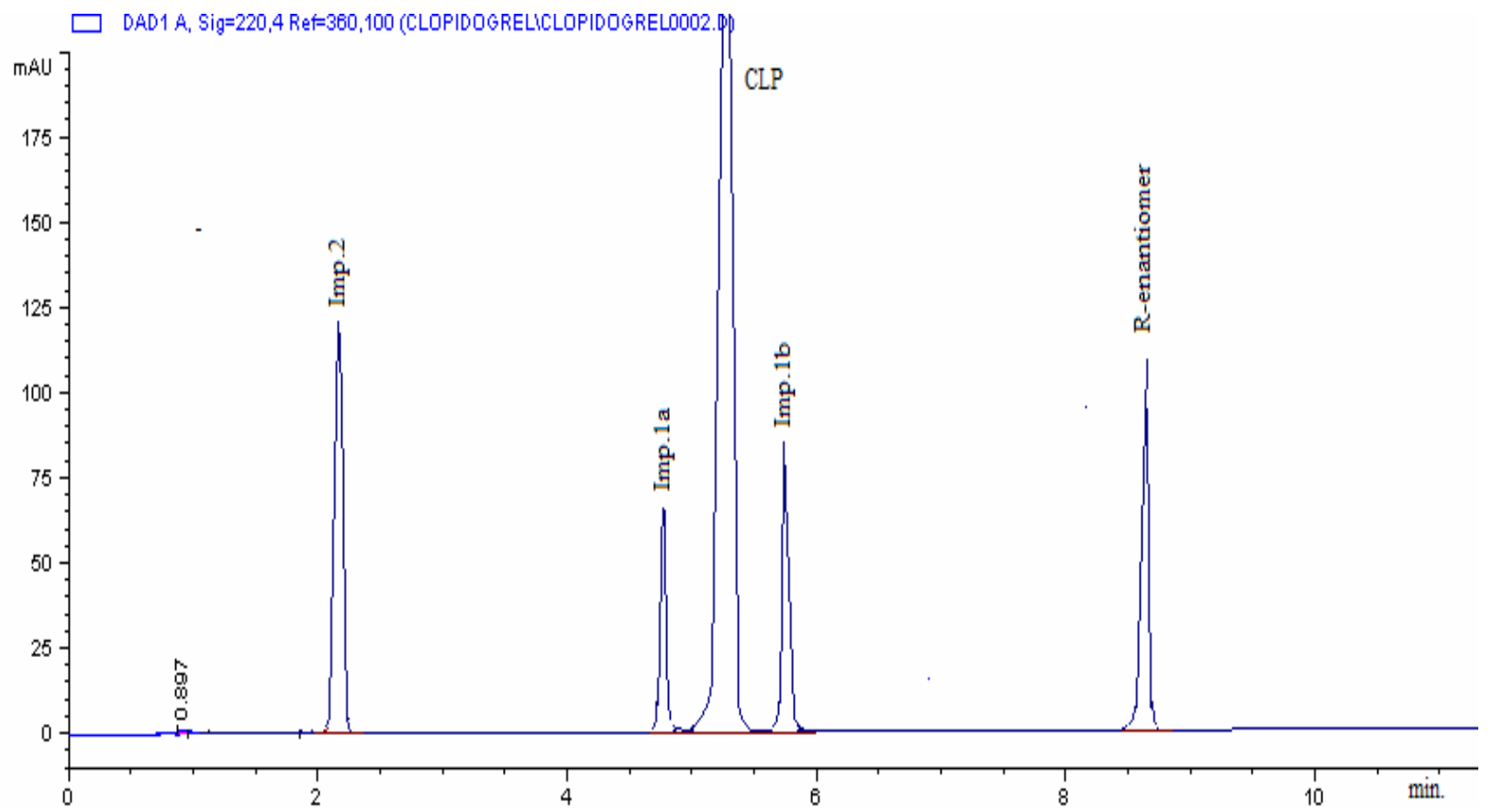

Fig. 3. Representative chromatogram of the test solution (ACN: Buffer solution $\mathrm{pH} 6.5(40: 60, \mathrm{v} / \mathrm{v})$ at $30^{\circ} \mathrm{C}$; flow rate of $\left.1.0 \mathrm{ml} / \mathrm{min}\right)$

The resolution values between peaks of Imp.1a/CLP and CLP/Imp.1b were 1.53 and 1.56 , respectively. All respective compounds were clearly separated and their corresponding peaks were sharply developed. Separation was obtained in $10.0 \mathrm{~min}$. The chromatographic parameters for the representative chromatogram are given in Table 3 .

Table 3

The chromatographic parameters for the representative chromatogram

\begin{tabular}{|c|c|c|c|c|c|}
\hline & \multicolumn{5}{|c|}{ Eluted peaks } \\
\hline & Imp. 2 & Imp. 1a & CLP & Imp. 1b & $R$-enantiomer \\
\hline$t_{\mathrm{r}}(\min )$ & 2.29 & 4.82 & 5.26 & 6.06 & 9.15 \\
\hline \multirow[t]{3}{*}{$k$} & 3.13 & 1.21 & 3.12 & 2.61 & 2.46 \\
\hline & \multicolumn{5}{|c|}{ Eluted peak pairs } \\
\hline & Imp. 2/Imp1a & Imp. 1a/CLP & CLP/Imp. 1b & $\operatorname{Imp}$ & R-enantiomer \\
\hline$R_{S}$ & 5.23 & 1.53 & 1.56 & & 8.47 \\
\hline$\alpha$ & 2.14 & 1.58 & 1.70 & & 2.46 \\
\hline
\end{tabular}

$t_{r}$ - retention time, $k$ - capacity factor, $\alpha$ - selectivity, $R s-$ resolution

The results obtained using this methodology clearly shows that it was possible to simultaneously systematically optimize the influence of: $\left(x_{1}\right)$ acetonitril content $(\mathrm{v} / \mathrm{v}, \%)$ in the mobile phase, $\left(x_{2}\right)$
$\mathrm{pH}$ value of mobile phase and $\left(x_{3}\right)$ column temperature on the separation of the investigated substances. 
Validation. After establishing the optimal conditions for the separation, the selectivity, linearity, precision, accuracy, limit of detection, and limit of quantification were determined for all the investigated substances. The assay is selective as all peaks were baseline separated with $R s$ values above 1.5 and no significant interfering peaks were

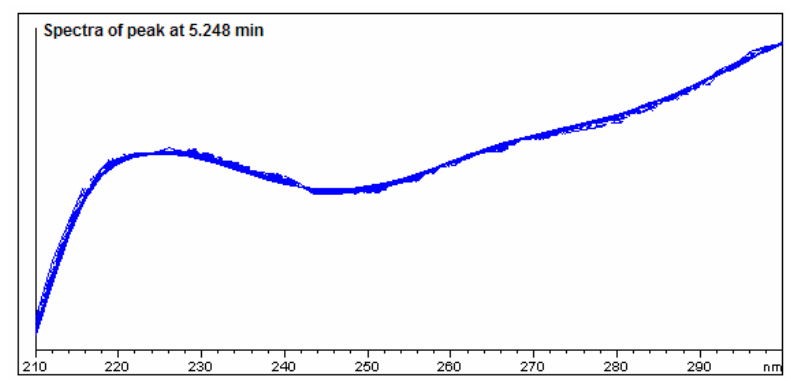

(a)

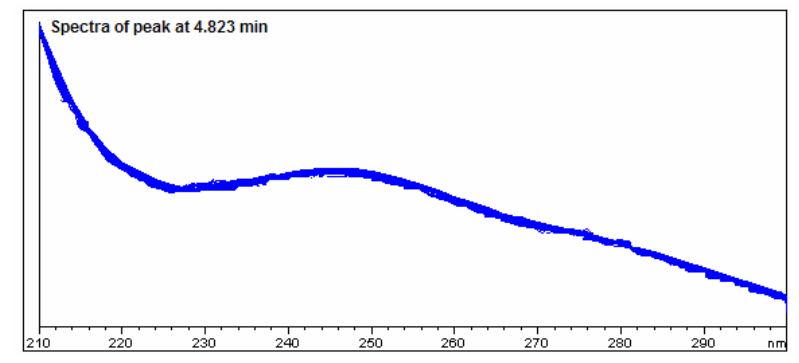

(c) observed at the retention time of the investigated substances. The peak purity for CLP and each related substance was assessed by comparing the spectra across a peak over 200 to $300 \mathrm{~nm}$ wavelengths, as shown in Fig. 4. Spectra were acquired at the upslope, the apex, and at the down slope of the peak.

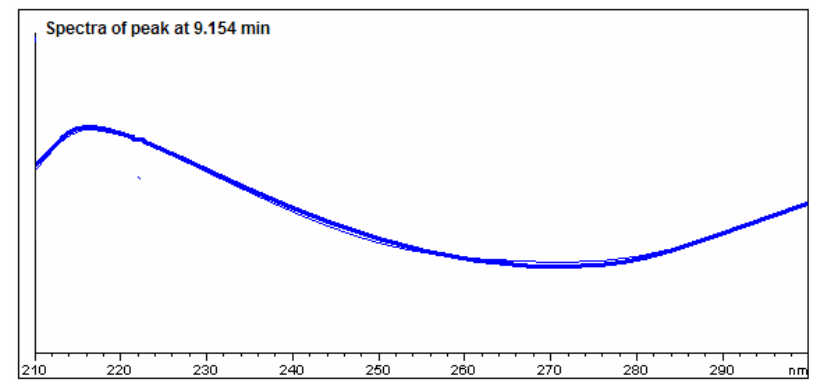

(b)

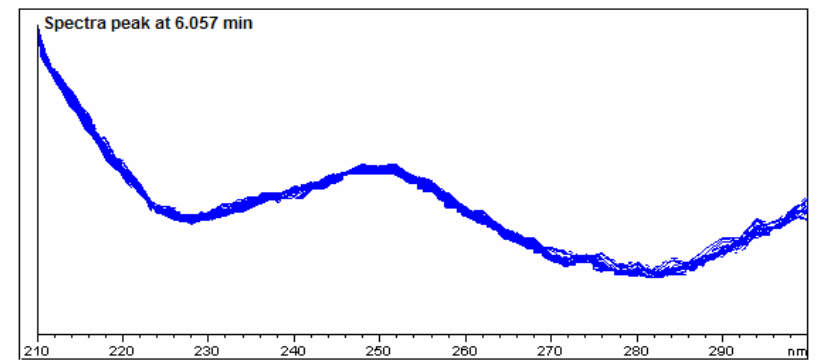

(d)

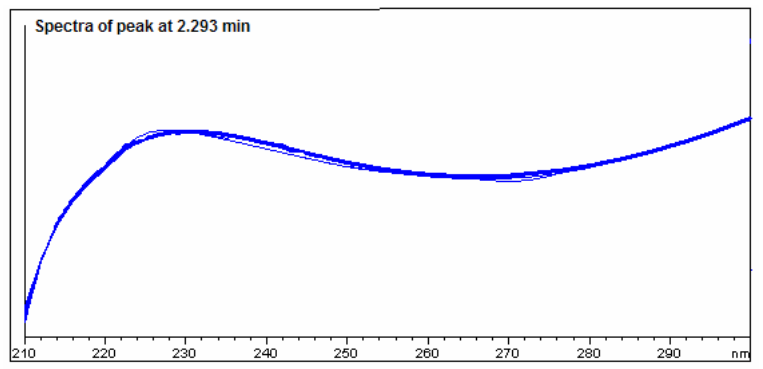

(e)

Fig. 4. Peak-purity evaluation by overlaying spectra of (a) clopidogrel ( $S$ - enantiomer); (b) clopidogrel ( $\mathrm{R}$ - anatiomer); (c) impurity $1 \mathrm{a} ;$ (d) impurity $1 \mathrm{~b}$ and (e) impurity 2

The results show that spectra overlay nicely, each point of the similarity ratio was below the threshold limit, and the difference between the spectra did not show a systematic pattern.

Linear relationships were obtained for the peak areas over the concentration range from 10 to $100 \mu \mathrm{g} \mathrm{ml}^{-1}$ for CLP and from 5 to $50 \mathrm{ng} \mathrm{ml}^{-1}$ for each related substance. The linear regression analysis indicated that the response of the HPLC system was linear for all investigated substances.
Limit of detection and limit of quantification values were attained according the IUPAC definition, $L O D_{(k=3)}=k \times S_{d(a)} / b, L O Q_{(k=10)}=k \times S_{d(a)} / b$, where $b$ is the slope of the calibration curve and $S_{d(a)}$ is the standard deviation of the intercept. The important calibration curve parameters: intercept $(a)$, slope $(b), S_{d(a)}$-standard deviation of the intercept, $S_{d(b)}$-standard deviation of the slope, correlation coefficient $\left(R^{2}\right)$, limit of detection $(L O D)$ and limit of quantification $(L O Q)$ are presented in Table 4. 
Table 4

\begin{tabular}{lccccc}
\multicolumn{6}{c}{ Calibration parameters } \\
\hline \hline Parameter & Imp. 2 & Imp. 1a & CLP & Imp. 1b & R-enantiomer \\
\hline$a$ & -0.162 & -0.193 & 1.342 & -0.273 & 2.646 \\
$b$ & 3.332 & 76.325 & 0.391 & 11.023 & 107.4 \\
Sa $\times 10^{-3}$ & 2.531 & 4.413 & 0.230 & 6.034 & 34.141 \\
$S b$ & 0.008 & 1.100 & 0.007 & 0.213 & 1.659 \\
$R^{2}$ & 0.9999 & 0.9998 & 0.9999 & 0.9998 & 0.9998 \\
LOD ng ml $^{-1}$ & 1.4 & 1.9 & 194.6 & 1.79 & 1.04 \\
LOQ ng ml $^{-1}$ & 4.2 & 5.7 & 589.7 & 5.44 & 3.17 \\
\hline \hline
\end{tabular}

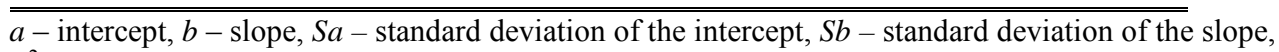
$R^{2}$ - coefficient of correlation, $L O D$ - limit of detection, $L O Q$ - limit of quantification

The important statistical values obtained from intra and inter-day precision and accuracy determinations, such as standard deviation (S) and coefficient of variation (CV), as well as the good recoveries, indicate that the assay was precise (standard deviations are very small; $\mathrm{CV}$ range from 1.48 to $2.61 \%$ for CLP and from 1.19 to $2.63 \%$ for its related compounds) and accurate (recovery values from 99.5 to $101.6 \%$ for CLP and from 98.9 to 101.7 for the related compounds). The accuracy was calculated as a percentage of the nominal concentration. The results for precision and accuracy of the proposed enantiospecific HPLC method are given in Table 5 .

Robustness testing. As defined by the ICH (International Conference on Harmonization of Technical Requirements for Registration of Pharmaceuticals for Human Use), Topic Q2 (R1) [16], the robustness of an analytical procedure refers to its capability to remain unaffected by small and deliberate variations in method parameters. In order to study the simultaneous variations of the factors on the considered responses, a multivariate approach using experimental design is recommended for robustness testing. The experimental design was carried out to investigate the behaviour of the response around the nominal values of the factors. The Design of Experiments (DoE) methodology has the advantages that it allows a complete study where all interaction effects are estimated and gives a description of an experimental region around a centre of interest with reliable interpolation $[17,18]$. Three factors were considered: $\left(x_{1}\right)$ acetonitril content $(\mathrm{v} / \mathrm{v}, \%)$ in the mobile phase, $\left(x_{2}\right) \mathrm{pH}$ of the mobile phase, and $\left(x_{3}\right)$ column temperature. The Central Composite Face Centered
(CCF) Design is widely employed because of its high efficiency with respect to the number of runs required. The design required $2^{k}+2 k+n=17$ runs, where $k$ is the number of parameters studied $(k=3)$ and $n$ the number of central points included $(n=3)$. Three repetitions are generally carried out in order to know the experimental error variance and to test the predictive validity of the model [11, 18]. The experimental plan is reported in Table 6.

The values used at the low $(-)$, central $(0)$ and high $(+)$ level, for $\mathrm{x}_{1}$ correspond to values of 25 , 30 and $35(\mathrm{v} / \mathrm{v}, \%)$, for $\mathrm{x}_{2}$ to values of $6.0,6.5$ and 7.0 , and for $\mathrm{x}_{3}$ to values of 25,30 and $35^{\circ} \mathrm{C}$, respectively. All experiments were performed in randomized order so as to minimize the effects of uncontrolled factors that may introduce a bias on the response and drift of the analytical method. The ranges examined were small deviations from the method settings, and the considered response was the measured resolution $\left(R_{s}\right)$ between each peak pair. A Chromatographic Response Function (CRF) was calculated for all 17 runs and it was used for evaluating the influence of the factors variation on the separation quality of CLP and its impurities. Multiple linear regressions were used to estimate the coefficients of the model representing the relationship between the response variables measured and the chromatographic parameters studied. Single coefficients describe the quantitative effect of a variable on the response, cross products the interaction between variables, and squared coefficients the non-linear effects. The coefficients are significant (different from the noise) when the confidence interval does not cross zero. The results are shown in Fig. 5. 
Table 5

Precision and accuracy of the proposed HPLC method

\begin{tabular}{|c|c|c|c|c|}
\hline & & Intra-day $(n=6)$ & & \\
\hline \multirow{4}{*}{ CLP } & Injected $\left(\mu \mathrm{g} \mathrm{ml}^{-1}\right)$ & Determined $\left(\mu \mathrm{g} \mathrm{ml}^{-1}\right)$ & $\mathrm{CV}(\%)$ & Accuracy $(\%)$ \\
\hline & 20.0 & $20.24 \pm 0.3^{*}$ & 1.48 & 101.2 \\
\hline & 50.0 & $50.90 \pm 0.8$ & 1.57 & 101.8 \\
\hline & 80.0 & $79.84 \pm 1.2$ & 1.50 & 99.8 \\
\hline \multirow{4}{*}{ Imp. 1a } & Injected (ng ml $\left.{ }^{-1}\right)$ & Determined $\left(\mathrm{ng} \mathrm{ml}^{-1}\right)$ & $\mathrm{CV}(\%)$ & Accuracy (\%) \\
\hline & 10 & $9.89 \pm 0.2$ & 2.02 & 98.9 \\
\hline & 25 & $25.42 \pm 0.4$ & 1.57 & 101.6 \\
\hline & 40 & $40.40 \pm 0.7$ & 1.73 & 101.0 \\
\hline \multirow{3}{*}{ Imp. 1b } & 10 & $10.12 \pm 0.2$ & 1.97 & 101.2 \\
\hline & 25 & $24.90 \pm 0.3$ & 1.20 & 99.6 \\
\hline & 40 & $39.88 \pm 0.7$ & 1.75 & 99.7 \\
\hline \multirow{3}{*}{ Imp. 2} & 10 & $10.09 \pm 0.2$ & 1.98 & 100.9 \\
\hline & 25 & $24.7 \pm 0.4$ & 1.62 & 98.9 \\
\hline & 40 & $40.24 \pm 0.9$ & 2.23 & 100.6 \\
\hline \multirow{3}{*}{$R$-enantiomer } & 10 & $10.10 \pm 0.2$ & 1.98 & 101.0 \\
\hline & 25 & $25.17 \pm 0.3$ & 1.19 & 100.7 \\
\hline & 40 & $39.96 \pm 0.8$ & 2.00 & 99.9 \\
\hline \multirow{5}{*}{ CLP } & & Inter-day $(n=12)$ & & \\
\hline & Injected $\left(\mu \mathrm{g} \mathrm{ml}^{-1}\right)$ & Determined $\left(\mu \mathrm{g} \mathrm{ml}^{-1}\right)$ & $\mathrm{CV}(\%)$ & Accuracy $(\%)$ \\
\hline & 20.0 & $20.32 \pm 0.4$ & 1.96 & 101.6 \\
\hline & 50.0 & $49.75 \pm 1.3$ & 2.61 & 99.5 \\
\hline & 80.0 & $80.67 \pm 1.2$ & 1.49 & 100.8 \\
\hline \multirow{4}{*}{ Imp. 1a } & Injected (ng ml ${ }^{-1}$ ) & Determined $\left(\mathrm{ng} \mathrm{ml}^{-1}\right)$ & $\mathrm{CV}(\%)$ & Accuracy (\%) \\
\hline & 10 & $10.71 \pm 0.20$ & 1.87 & 100.7 \\
\hline & 25 & $24.93 \pm 0.4$ & 1.53 & 99.9 \\
\hline & 40 & $40.25 \pm 0.7$ & 1.75 & 100.5 \\
\hline \multirow{3}{*}{ Imp. 1b } & 10 & $10.43 \pm 0.3$ & 2.42 & 100.4 \\
\hline & 25 & $24.95 \pm 0.4$ & 1.48 & 99.7 \\
\hline & 40 & $39.91 \pm 0.7$ & 1,66 & 99.8 \\
\hline \multirow{3}{*}{ Imp. 2} & 10 & $10.24 \pm 0.2$ & 2.32 & 100.2 \\
\hline & 25 & $24.82 \pm 0.5$ & 2.16 & 99.4 \\
\hline & 40 & $39.63 \pm 0.6$ & 1.67 & 99.0 \\
\hline \multirow{3}{*}{$R$-enantiomer } & 10 & $9.93 \pm 0.3$ & 2.63 & 99.3 \\
\hline & 25 & $25.43 \pm 0.4$ & 1.48 & 101.7 \\
\hline & 40 & $40.21 \pm 0.8$ & 1.91 & 100.6 \\
\hline
\end{tabular}

$* S-$ standard deviation

Table 6

Experimental plan for robustness testing

\begin{tabular}{lcccccccccccccccccc}
\hline \hline \multicolumn{11}{c}{ Exp. No } \\
\hline Factors & 1 & 2 & 3 & 4 & 5 & 6 & 7 & 8 & 9 & 10 & 11 & 12 & 13 & 14 & 15 & 16 & 17 \\
$x_{1}$ & - & + & - & + & - & + & - & + & 0 & 0 & 0 & - & + & 0 & 0 & 0 & 0 \\
$x_{2}$ & - & - & + & + & - & - & + & + & 0 & 0 & 0 & 0 & 0 & - & + & 0 & 0 \\
$x_{3}$ & - & - & - & - & + & + & + & + & 0 & 0 & 0 & 0 & 0 & 0 & 0 & - & + \\
\hline \hline
\end{tabular}




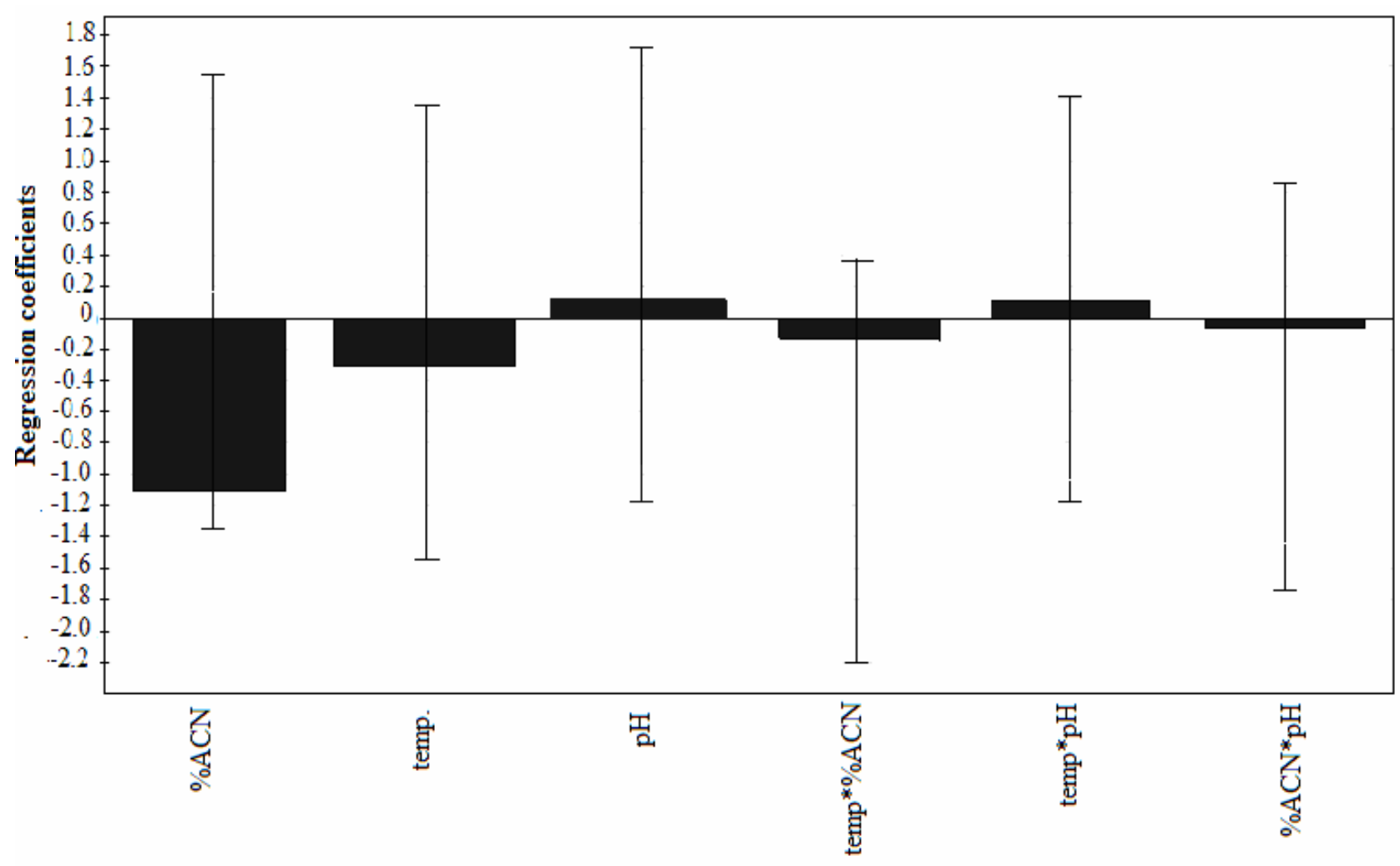

Variables and interactions

Fig. 5. Regression coefficient plot (\%ACN: acetonitrile content in the mobile phase, $\mathbf{p H}$ : $\mathrm{pH}$ value of the mobile phase, temp: column temperature, ${ }^{\circ} \mathrm{C}$ )

The coefficient plot displays the regression coefficients with the confidence intervals. The plot consists of bars that correspond to the regression coefficients, with the magnitude of the effects proportional to the regression coefficients. The $95 \%$ confidence limits are expressed by using error bars. A regression coefficient smaller than the error bar interval indicates that the variation in the response produced by changing that chromatographic parameter is smaller than the experimental error. Therefore the effect of that variable is considered not significant. The results show that the separation under the examined conditions was principally influenced by the ACN content in the mobile phase and column temperature. They both have a negative effect on the CRF, which means that an increase in the percentage of acetonitrile in the mobile phase or an increase of the column temperature decrease the resolution between all peak pairs. The influence of the $\mathrm{pH}$ value of the mobile phase was not significant. No major interactions were found. The statistical analysis of the applied design is shown in Fig. 6.

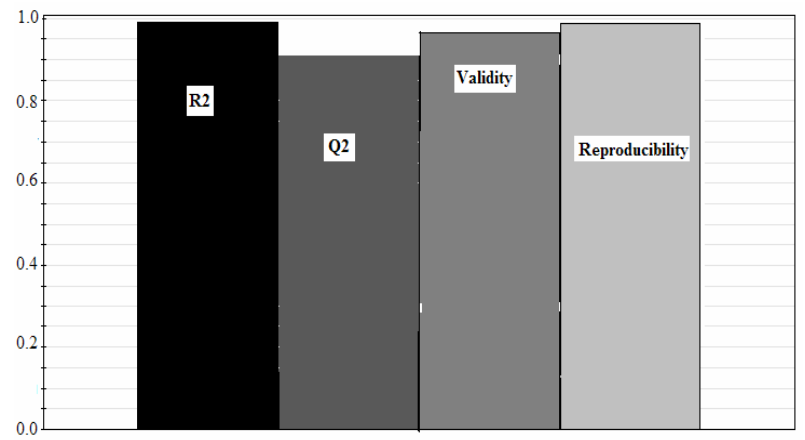

Fig. 6. The statistical analysis of the Central Composite Face Centered design

The $R^{2}$ value (percent of the variation of the response that can be explained by the CCF design) of $0.99, Q^{2}$ value (percentage of the variation of the response predicted by the design), validity of 0.89 and reproducibility (variation of the response at the center point compared to the total variation of the response) of 0.98 showed that the model represents the phenomenon quite well and the variation of CRF was correctly related to the varia- 
tion of the factors, showing a good agreement between experimental and predicted values. In conclusion, the analysis confirmed that the method is robust for all factors.

\section{CONCLUSION}

The determination of the levels of clopidogrel hydrogen sulphate related compounds in the therapeutically active substances is the most important step in the quality control of such substances. The linear model obtained demonstrates a large influence of the amount of acetonitrile in the mobile phase and smaller, but significant influence of column temperature on the resolution between the investigated substances. Complete and exact information of resolution modeling was obtained by RSM, giving a possibility for prediction. Valuable information about robustness of the method was obtained by CCF design, using resolution as an important component of the CRF. The methodology proposed represents an efficient and easily accomplishable approach in resolving the problem of searching for optimum HPLC conditions. The proposed enantiospecific RP-HPLC method is simple, rapid and robust assay for impurity determination, and can provide acceptable linearity, accuracy, precision and selectivity. The method permits simultaneous determination of clopidogrel hydrogen sulphate and its related compounds specified as impurities in drug substance.

\section{REFERENCES}

[1] B. Jarvis, K. Simpson, Clopidogrel: A Review of its Use in the Prevention of Atherothrombosis, Drugs, 60 (2), 347-377 (2000).

[2] K. Moshfegh, M. Redondo, F. Julmy, W. A. Wuillemin, M. U. Gebauer, A. Haeberli, and B. J. Meyer, Antiplatelet effects of clopidogrel compared with aspirin after myocardial infarction: enhanced inhibitory effects of combination therapy, J. Am. Coll. Cardiol., 36 (3), 699-705 (2000).

[3] T. L. Lenz, A. F. Wilson, Clinical Pharmacokinetics of Antiplatelet Agents Used in the Secondary Prevention of Stroke, Clin. Pharmacokinet., 42, 909-920, (2003).
[4] A. Mitakos, I. Panderi, A validated LC method for the determination of clopidogrel in pharmaceutical preparations, J. Pharm. Biomed. Anal., 28, 431-438 (2002).

[5] Y. Gomez, E. Adams, J. Hoogmartens, Analysis of purity in 19 drug products tablets containing clopidogrel: 18 copies versus the original brand, J. Pharm. Biomed. Anal., 34, 341-348 (2004).

[6] H. Ksycinska, P. Rudzki, M. Bukowska-Kiliszek, Determination of clopidogrel metabolite (SR26334) in human plasma by LC-MS, J. Pharm. Biomed. Anal., 41, 533539 (2006).

[7] A. Mitakos, I. Panderi, Determination of the carboxylic acid metabolite of clopidogrel in human plasma by liquid chromatography-electrospray ionization mass spectrometry, Anal. Chim. Acta, 505, 107-114, (2004).

[8] S. S. Singh, K. Shama, D. Barot, P. R. Mohan, V. B. Lohray, Estimation of carboxylic acid metabolite of clopidogrel in Wistar rat plasma by HPLC and its application to a pharmacokinetic study, J. Chromatogr. B, 821, 173180 (2005).

[9] International Conference on Harmonization of Technical Requirements for Registration of Pharmaceuticals for Human Use. Topic Q3A (R2), Impurities in New drug substances (2006)

[10] N. Matthijs, C. Perrin, M. Maftouh, D. L. Massart, Y. Vander Heyden, Definition and system implementation of strategies for method development of chiral separation in normal-or reversed-phase liquid chromatography using polysaccharide-based stationary phases, J. Chromatogr. A, 1041, 119-133, (2004).

[11] T. Lundsted, E. Seifert, L. Abramo, B. Thelin, A. Nystorm, J. Pettersen and R. Bergman, Experimental design and optimization. Chemom. Intell. Lab. Syst., 42, 3-40, (1998).

[12] European Pharmacopeia, $6^{\text {th }}$ Edition, Concil of Europe, Strasbourg, 2007, pp.74.

[13] P. W. Araujo, R. G. Brereton, Experimental design, II. Optimization. Trends Anal Chem., 15, 63-68 (1996).

[14] S. N. Deming and S. L. Morgan, Experimental design: A chemometric approach, Elsevier, Amsterdam, Netherlands. 1993.

[15] D. Bylund, A. Bergens and S. P. Jacobsson, Optimization of Chromatographic Separations by Use of a Chromatographic Response Function, Empirical Modeling and Multivariate Analysis. Chromatographia, 44, 74-80 (1997).

[16] International Conference on Harmonization of Technical Requirements for Registration of Pharmaceuticals for Human Use. Topic Q2 (R1), Validation of Analytical Procedures: Text and Methodology, 2006.

[17] H. Fabre, Robustness testing in liquid chromatography and capillary electrophoresis. J. Pharm. Biomed. Anal., 14, 1125-1132 (1996).

[18] G. A. Lewis, D. Mathieu and R. Phan-Tan-Luu, Pharmaceutical Experimental Design, Marcel Decker, New York USA 1999. 